\title{
The Role of Specificity and Apologies in Excuse Messages Following Train Delay
}

\author{
Emiel Cracco $^{1 *}$ \\ Nicolas Dirix ${ }^{1}$ \\ Christopher P. Reinders Folmer ${ }^{2}$
}

\begin{abstract}
An important issue in public transport is punctuality. Because delays are often caused by external factors, an efficient way to mitigate passengers' negative reactions is to point out these factors in an excuse. The current study investigated whether excuses following train delay can be optimized by making minor changes to their content. Specifically, we compared the effectiveness of specific and non-specific excuses. Furthermore, we investigated whether adding different types of an apology influenced the effectiveness of the excuse. The results indicated that specific excuses resulted in more forgiveness and a reduced intention to avoid public transport in the future. Further analyses showed that specific excuses were more acceptable and were therefore more successful at reducing perceived responsibility. The presence or absence of an apology did not influence excuse effectiveness. These findings suggest that minor adjustments to the communication strategy of public transport organizations can reduce passenger loss due to delays.
\end{abstract}

Keywords: trust repair, public transport, delay, excuse, apology

\section{Introduction}

When railway passengers purchase a ticket, they expect their train to arrive on time. However, these expectations are often violated. In Belgium, for instance, $11 \%$ of the trains in 2015 were either delayed by more than six minutes or cancelled (Infrabel, 2016). Research has shown that the inability to meet consumer expectations is perceived as a

\footnotetext{
'Department of Experimental Psychology, Ghent University, Henri Dunantlaan 2, 9000 Ghent, Belgium ${ }^{2}$ Department of Private Law, Behavioural Approaches to Contract and Tort, Erasmus School of Law, Erasmus University Rotterdam, Burgemeester Oudlaan 50, 3062 PA Rotterdam, the Netherlands *Corresponding author. E-mail: emiel.cracco@ugent.be Emiel Cracco and Nicolas Dirix contributed equally to this work.
} 
violation of trust (Wang \& Huff, 2007), which leads to complaints (Brown \& Beltramini, 1989; Folkes, Koletsky, \& Graham, 1987), negative word of mouth (Brown \& Beltramini, 1989; Wang \& Huff, 2007), and reduced repurchase intention (Folkes et al., 1987; Wang \& Huff, 2007). In line with this evidence, recent polls indicate that the current situation of frequent delays has culminated in a general feeling of dissatisfaction among the Belgian railway passengers (Test-Aankoop, 2015). To avoid passenger loss, an important question is therefore how trust can be restored after a train delay.

Previous work has shown that the consequences of trust violation strongly depend on how the transgression is perceived. For example, studies have shown that the influence of inadequate service provision was reduced when consumers did not expect the event to reoccur (Folkes et al., 1987; Wang \& Huff, 2007), evaluated the inconvenience as small (Brown \& Beltramini, 1989), or felt that the supplier had no control over the situation (Brown \& Beltramini, 1989; Folkes et al., 1987). As a result, an interesting approach to repair trust is to provide an excuse that lists the external factors contributing to the transgression (Kim, Dirks, \& Cooper, 2009; Shaw, Wild, \& Colquitt, 2003; Snyder \& Higgins, 1988). Interestingly, train delays are often the result of factors beyond the control of the railway company. In Belgium, for example, 39.4\% of the delays were caused by external factors such as cable theft (Infrabel, 2016). An efficient strategy to mitigate the reputational and financial costs associated with train delay is therefore to communicate these external factors to the passengers in a general announcement. In line with this suggestion, delay announcements typically consist of an excuse (e.g., "The train with destination Antwerp is delayed by 15 minutes due to a technical failure") followed by an apology (e.g., "Our apologies for the delay"). However, excuses should be used with care as studies indicate that unconvincing explanations may have unintended harmful effects instead (Ferrin, Kim, Cooper, \& Dirks, 2007; Kim et al., 2009). Therefore, the goal of the current study was to investigate how train delay announcements can be optimized by making minor changes to their content. Based on previous research, we will first investigate whether train delay announcements are more effective when they include a specific rather than an abstract excuse (Frey \& Cobb, 2010; Greenberg, 1994; Shapiro et al., 1994). We will furthermore investigate whether apologies have a positive or a negative influence when they are combined with an excuse (Kim et al., 2009; Tomlinson, Dineen, \& Lewicki, 2004). Finally, we will investigate whether the influence of an apology depends on whether it refers to the cause or to the consequence of the delay (Kim et al., 2009). As such, the present work aims to provide insight in how railway companies can augment their communication strategy to mitigate the negative impact of train delays.

\section{Specificity of Excuses}

Delay announcements often contain an excuse (e.g., "... due to a technical failure ..."). A widely used framework to interpret the influence of excuses is fairness theory (Folger \& Cropanzano, 2001; Frey \& Cobb, 2010; Gilliland et al., 2001; Shaw et al., 2003). Applied to train delays, this theory states that the degree to which passengers hold the railway company responsible depends on whether the delay could have been prevented (i.e., 
could counterfactual), on whether the delay should have been prevented (i.e., should counterfactual), and on whether they would have been better off without the delay (i.e. would counterfactual). Specifically, fairness theory postulates that the sense of injustice experienced by delayed railway passengers will depend on the number of questions to which the answer is affirmative (Shaw et al., 2003).

Because the goal of an excuse is to deflect responsibility to external factors, their effect can be situated at the level of could counterfactuals (Shaw et al., 2003). It is well documented that individuals automatically overestimate the internal and underestimate the external factors that contributed to a transgression (Kim et al., 2009). As a result, railway passengers are likely to initially assume that the delay could have been prevented. However, providing information on the contributing external factors may cause passengers to reconsider their initial internal attribution. It is assumed that such a shift from internal to external attribution will decrease the perceived responsibility of the railway company and will therefore reduce the negative consequences associated with the delay (Frey \& Cobb, 2010; Gilliland et al., 2001; Shaw et al., 2003).

Importantly, research on excuses in interpersonal and organizational settings has identified that their effectiveness strongly depends on whether or not they are acceptable (Bies, Shapiro, \& Cummings, 1988; Frey \& Cobb, 2010; Mansour-Cole \& Scott, 1998; Mellor, 1992; Shapiro, 1991; Shaw et al., 2003). Stated in terms of fairness theory, an excuse can be thought of as acceptable when it is legitimate and a legitimate excuse is more likely to reduce the perceived responsibility for a transgression. However, to successfully attribute a train delay to external factors it is especially relevant to know which factors constitute an acceptable excuse. Studies on this matter have revealed that acceptability is influenced both by the source and the content of the excuse. In particular, these studies indicated that an excuse should ideally be delivered in a sensitive way (Greenberg, 1993, 1994; Shapiro, Buttner, \& Barry, 1994) by a trustworthy person (Greenberg, 1993) and contain detailed information regarding the external factors that contributed to the transgression (Frey \& Cobb, 2010; Greenberg, 1994; Shapiro et al., 1994).

Whereas sensitivity and trustworthiness are difficult to manipulate in the short and formal messages that are used to communicate train delays, detailed excuses can be formed with minor effort. Therefore, the first goal of the current study was to investigate the influence of message specificity on the effectiveness of train delay excuses. Furthermore, to understand the process through which message specificity operates, we will additionally examine the role of two mediating variables. In line with previous work, we will first explore the mediating role of acceptability (Frey \& Cobb, 2010). In addition, we will also explore the influence of perceived responsibility. In particular, we will test the assumption that acceptable excuses are more effective because they are more successful at reducing doubt concerning the responsibility of the railway company for the delay (Frey \& Cobb, 2010; Gilliland et al., 2001; Shaw et al., 2003). 


\section{Combining Excuses with Apologies}

Following the excuse, delay announcements frequently contain an apology (e.g., "... our apologies for the delay"). An apology can be defined as a statement in which the perpetrator admits responsibility and conveys regret for a trust violation. Although it entails an admission of guilt, it is assumed that such a message is successful because it communicates remorse and the intention to avoid a similar violation in the future (Ferrin et al., 2007; Kim et al., 2009). Indeed, the effectiveness of apologies is well established in organizational, interpersonal, and commercial settings (Bisel \& Messersmith, 2012; Ferrin et al., 2007; Koehn, 2013; Ohbuchi, Kameda, \& Agarie, 1989; Patel \& Reinsch, 2003; Risen \& Gilovich, 2007; Roschk \& Kaiser, 2013). However, not much is known about the influence of apologies in the context of an excuse. According to an influential framework, excuses and apologies operate at a different level of trust repair (Kim et al., 2009). In particular, it is assumed that the success of an excuse depends on whether or not it is able to attribute the transgression to an external cause. Apologies, on the other hand, entail a confession of guilt and could therefore undermine the external shift intended by the excuse (Kim et al., 2009). In support of this idea, it has been shown that apologies are more effective when they are paired with an internal attribution compared with an external attribution (Tomlinson, Dineen, \& Lewicki, 2004).

In light of the above, the second goal of the present study was to examine the influence of apologies on the effectiveness of train delay excuses. Because apologies imply a confession of guilt, it can be expected that apologizing for the delay has a negative impact on the legitimacy of the excuse. However, this may depend on the content of the apology. Specifically, an apology can refer to the cause of the delay (e.g., "our apologies for the incident") or to the consequence of the delay (e.g., "our apologies for the inconvenience"). While an apology referring to the cause contains an internal attribution, an apology referring to the consequence does not. Instead, it brings across an empathic response. Consequently, it can be hypothesized that a cause apology may have a negative influence on the effectiveness of the excuse, whereas a consequence apology may have a positive influence.

To conclude, the current study aims to study how excuses following train delay can be optimized. First, we will study whether specific excuses are more effective than non-specific excuses. Second, we will examine if the addition of an apology has a positive or negative influence on excuse effectiveness and whether this depends on the type of apology.

\section{Method}

\section{Participants}

A sample of 128 Dutch-speaking Belgian participants took part in the study (82 females, 42 males, $M_{\text {age }}=25.53, S D_{\text {age }}=11.13$ ). The majority of the sample (88) was recruited online through social media advertisements and the remaining 40 participants were 
first year psychology students of Ghent University who received partial course credit in exchange for their participation. Missing descriptive data were present for four participants. That is, three participants entered neither age nor gender information and one participant entered only age information. Participants indicated to make on average 15.49 train journeys per month (Table 2). Subjects were randomly assigned to the different conditions of the Excuse Type (specific or non-specific) $x$ Apology Type (no apology, cause apology, consequence apology) design. Importantly, randomization was performed separately for credit students and social media volunteers to ensure that recruitment method was not confounded with the experimental manipulations.

\section{Design and Procedure}

Participants were asked to read and imagine a scenario (Supplementary Material). The scenario described a situation in which the subject was waiting for a train when it was announced that the train would be delayed by 20 minutes. The announcement started with an excuse. Importantly, the excuse could be either specific ("due to a copper theft in the vicinity of Lokeren") or non-specific ("due to problems on the railway track"). Following the excuse there was either no apology, an apology referring to the cause of the delay ("our apologies for this incident"), or an apology referring to the consequence of the delay ("our apologies for the inconvenience")'. After participants had read the scenario, they were asked to answer a number of questions that assessed the effectiveness of the excuse. Finally, participants were asked how often they take the train and how often they are confronted with train delays.

\section{Measures}

All items were measured on a 7-point Likert scale going from "Strongly Disagree" to "Strongly Agree". Example items are translated from Dutch to English. The full set of items is available in Supplementary Material.

Manipulation Check. The effectiveness of the manipulation was measured by assessing excuse specificity, excuse realism, and apology perception. The specificity of the excuse was measured with four items $(\alpha=0.93)$. An example item is: "I think the explanation for the delay is specific". The realism of the excuse was measured with three items $(\alpha=0.83)$. An example item is: "I find the cause of the delay unlikely" (reverse scored). Finally, two questions were used to check whether the apology was perceived as an apology that referred to the cause or as an apology that referred to the consequence, namely "I think the railway company apologized for the event that caused the delay" (cause) and "I think the railway company apologized for the inconvenience I experienced due to the delay" (consequence). Note that these last two questions were only answered by participants for whom the announcement contained an apology $(\mathrm{N}=83)$.

Mediator Variables. The acceptability of the excuse was evaluated with six items ( $\alpha=$ 0.85) based on previous research (Frey \& Cobb, 2010; Riordan, Marlin, \& Kellogg, 1983; Shapiro, 1991; Shapiro et al., 1994). An example item is: "The explanation is acceptable". 
The perceived responsibility of the railway company was measured with three items $(\alpha=0.77)$. An example item is: "I think the railway company could have avoided this delay".

Outcome Variables. The effectiveness of the excuse was assessed by measuring forgiveness, revenge, avoidance, benevolence, and complaints. The degree of forgiveness was evaluated with five items ( $\alpha=0.89$ ) based on the study of Subkoviak et al. (1995). An example item is: "After hearing this explanation, I could forgive the railway company for the delay". Items for revenge, avoidance, and benevolence were adapted from the Transgression-Related Interpersonal Motivations Inventory (McCullough, Root, \& Cohen, 2006). The tendency to take revenge was measured with three items $(\alpha=0.88)$. An example item is: "Despite hearing this explanation, I would hope that the railway company gets what it deserves". The degree to which participants wanted to avoid train travel as a result of the delay was measured with six items $(\alpha=0.88)$. An example item is: "Despite this explanation, the delay would encourage me to no longer travel by train". Benevolence towards the railway company was measured by means of two items ( $\alpha=$ 0.66). An example item is: "Even though I am disadvantaged, I would have goodwill for the railway company after hearing this explanation". Finally, the tendency to complain was assessed by four items $(\alpha=0.69)$. An example item is: "Despite this explanation, the delay would encourage me to complain to the train conductor".

Control Variables. The frequency of train travel was measured by asking "On average, how many times per month do you take the train?" and the frequency of train delay was measured by asking "On average, how many times per month is your train delayed?".

\section{Analyses}

All analyses were performed with SPSS for windows 21.0, except for the Bayesian analysis which was performed with JASP (Love et al., 2015) and the path analysis which was performed in R (R Development Core Team, 2013) with the lavaan package (Rosseel, 2012). P-values in the main analysis were corrected for testing multiple dependent variables according to Holm's procedure (Holm, 1979). The Bayes factors (BFs) obtained in the Bayesian analysis were interpreted according to Jeffreys (1961) with $1<\mathrm{BF} \leq 3$ indicating anecdotal evidence, $3<\mathrm{BF} \leq 10$ indicating substantial evidence, and $\mathrm{BF}>$ 10 indicating strong evidence. BFs measure the evidence for hypothesis $A$ relative to hypothesis B. For example, a BF of 3 indicates that the data is 3 times more likely under hypothesis $A$ than under hypothesis $B$.

One participant was excluded from all analyses because of excessive missing data (i.e., 21\%). In addition, one participant was not included in the manipulation check analyses because no data was recorded for the relevant variables. For the other participants, we first performed Little's MCAR test to examine if there was a pattern in the missing data $(<7 \%)$. This revealed a normed $\chi^{2}$ of 1.11 . We therefore performed expectationmaximization to estimate the missing values at the item level. 


\section{Results}

\section{Manipulation Check}

The manipulation check revealed that the specific excuse was perceived as more specific than the non-specific excuse, $t(124)=12.39, p<0.001$, but not as more realistic, $t(124)$ $=1.28, p=0.203$ (Table 1). However, the cause apology was not perceived as referring more to the cause than the consequence apology, $t(80)=1.61, p=0.111$, and the consequence apology was not perceived as referring more to the consequence than the cause apology, $t(80)=0.71, p=0.483$ (Table 1).

TABLE 1.

Means and standard deviations of the manipulation check separately for the different conditions (columns) and dependent variables (rows)

\begin{tabular}{|lc|c|c|c|}
\cline { 2 - 5 } \multicolumn{1}{c|}{} & \multicolumn{2}{c|}{ Non-Specific } & \multicolumn{2}{c|}{ Specific } \\
\cline { 2 - 5 } \multicolumn{1}{c|}{} & Cause & Consequence & Cause & Consequence \\
\hline \multirow{2}{*}{ Specificity } & 2.24 & $\begin{array}{c}1.92 \\
(0.81)\end{array}$ & $\begin{array}{c}4.19 \\
(1.21)\end{array}$ & $\begin{array}{c}4.67 \\
(1.14)\end{array}$ \\
\hline \multirow{2}{*}{ Realism } & 5.38 & 4.91 & 5.43 & 5.37 \\
& $(1.18)$ & $(1.03)$ & $(1.19)$ & $(1.27)$ \\
\hline \multirow{2}{*}{ Cause } & 3.90 & 3.18 & 4.67 & 4.16 \\
& $(1.97)$ & $(1.62)$ & $(1.74)$ & $(1.95)$ \\
\hline \multirow{2}{*}{ Consequence } & 5.40 & 5.50 & 5.43 & 5.74 \\
& $(1.47)$ & $(1.23)$ & $(1.29)$ & $(1.05)$ \\
\hline
\end{tabular}

\section{Excuse Specificity and Type of Apology}

To test the influence of Excuse Type and Apology Type on the evaluation of the excuse (Table 2), we first conducted separate ANCOVAs for each mediator and outcome variable with Excuse Type (non-specific or specific) and Apology Type (none, cause, or consequence) as factors and with Train Travel Frequency and Train Delay Frequency as covariates. As can be seen in Table 3, the main effect of Excuse Type was significant for acceptability, perceived responsibility, forgiveness, and avoidance. The main effect of Apology Type and the interaction between Excuse Type and Apology Type produced no significant effects. The results indicated that participants who received a specific excuse rated the excuse as more acceptable. Moreover, these participants were less likely to hold the railway company responsible for the delay, were more likely to forgive the railway company for the delay, and expressed a reduced intention to avoid train travel in the future. The presence of an apology did not have an influence on the outcome of the excuse. 
TABLE 2.

Means and standard deviations of the Excuse Type

$x$ Apology Type analysis separately for the different conditions (columns) and dependent variables (rows)

\begin{tabular}{|lc|c|c|c|c|c|}
\cline { 2 - 7 } \multicolumn{1}{c|}{} & \multicolumn{3}{c|}{ Non-Specific } & \multicolumn{3}{c|}{ Specific } \\
\cline { 2 - 7 } \multicolumn{1}{c|}{} & Cause & Consequence & None & Cause & Consequence & None \\
\hline \multirow{2}{*}{ Acceptability } & 4.80 & 4.22 & 4.32 & 5.45 & 5.31 & 5.41 \\
& $(1.50)$ & $(1.02)$ & $(1.07)$ & $(1.04)$ & $(0.83)$ & $(0.97)$ \\
\hline \multirow{2}{*}{ Responsibility } & 3.17 & 3.70 & 3.86 & 2.70 & 2.65 & 2.58 \\
& $(1.12)$ & $(0.91)$ & $(1.27)$ & $(1.11)$ & $(1.11)$ & $(1.05)$ \\
\hline \multirow{2}{*}{ Forgiveness } & 4.58 & 3.87 & 3.82 & 4.90 & 5.39 & 4.83 \\
& $(1.50)$ & $(1.22)$ & $(1.28)$ & $(1.34)$ & $(1.04)$ & $(1.35)$ \\
\hline \multirow{2}{*}{ Benevolence } & 4.70 & 4.07 & 4.11 & 4.58 & 4.93 & 4.64 \\
& $(1.32)$ & $(1.24)$ & $(1.56)$ & $(1.40)$ & $(1.09)$ & $(1.47)$ \\
\hline \multirow{2}{*}{ Avoidance } & 2.88 & 3.08 & 2.56 & 2.10 & 2.20 & 2.27 \\
& $(1.40)$ & $(1.25)$ & $(1.22)$ & $(1.22)$ & $(1.19)$ & $(1.15)$ \\
\hline \multirow{2}{*}{ Revenge } & 2.25 & 2.21 & 2.10 & 1.54 & 1.59 & 2.26 \\
& $(1.46)$ & $(1.48)$ & $(1.60)$ & $(0.64)$ & $(0.71)$ & $(1.57)$ \\
\hline \multirow{2}{*}{ Complain } & 3.01 & 3.16 & 3.09 & 2.73 & 2.91 & 2.97 \\
& $(1.10)$ & $(0.71)$ & $(1.08)$ & $(1.18)$ & $(0.94)$ & $(1.14)$ \\
\hline \multirow{2}{*}{ Train Travel } & 13.20 & 19.00 & 14.86 & 15.57 & 16.85 & 13.45 \\
& $(11.29)$ & $(16.71)$ & $(12.88)$ & $(13.70)$ & $(12.81)$ & $(11.57)$ \\
\hline \multirow{2}{*}{ Train Delay } & 7.45 & 9.38 & 5.09 & 5.71 & 5.55 & 6.55 \\
& $(10.42)$ & $(11.68)$ & $(5.48)$ & $(6.07)$ & $(5.46)$ & $(8.42)$ \\
\hline
\end{tabular}

TABLE 3.

Results of the Excuse Type $x$ Apology Type ANCOVA

\begin{tabular}{|l|c|c|c|c|c|c|}
\cline { 2 - 7 } \multicolumn{1}{c|}{} & \multicolumn{2}{c|}{ Excuse } & \multicolumn{2}{c|}{ Apology } & \multicolumn{2}{c|}{ Excuse x Apology } \\
\cline { 2 - 7 } \multicolumn{1}{c|}{} & $F(1,119)$ & $\eta_{\mathrm{p}}{ }^{2}$ & $F(2,119)$ & $\eta_{\mathrm{p}}{ }^{2}$ & $F(2,119)$ & $\eta_{\mathrm{p}}{ }^{2}$ \\
\hline Acceptability & $22.31^{* * *}$ & 0.16 & 1.42 & 0.02 & 1.03 & 0.02 \\
\hline Responsibility & $21.16^{* * *}$ & 0.15 & 0.99 & 0.02 & 2.18 & 0.04 \\
\hline Forgiveness & $15.33^{* * *}$ & 0.11 & 1.48 & 0.02 & 2.29 & 0.04 \\
\hline Benevolence & 2.29 & 0.02 & 0.53 & 0.01 & 1.59 & 0.03 \\
\hline Avoidance & $7.73^{*}$ & 0.06 & 0.40 & 0.01 & 0.33 & 0.01 \\
\hline Revenge & 2.36 & 0.02 & 0.87 & 0.01 & 1.12 & 0.02 \\
\hline Complaints & 1.04 & 0.01 & 0.36 & 0.01 & 0.02 & 0.00 \\
\hline
\end{tabular}

Note. ${ }^{*} p<0.05,{ }^{* *} p<0.01,{ }^{* * *} p<0.001$. P-values were corrected for testing multiple dependent variables according to Holm's procedure (Holm, 1979). Train Travel Frequency and Train Delay Frequency were included as covariates in the analysis.

To further evaluate the influence of Excuse Type and Apology Type, we additionally performed a IZS Bayes factor ANOVA (Rouder, Morey, Speckman, \& Province, 2012) with default prior scales and with both Train Travel Frequency and Train Delay Frequency as nuisance variables (Table 4). We first compared a model with a single main effect for Excuse Type with the Null Model. This revealed strong evidence in favor of the Excuse Type Model for acceptability ( $B F=4342.69)$, responsibility ( $B F=4640.88)$, forgiveness ( $B F=466.31)$, and avoidance $(B F=22.50)$. Anecdotal evidence for the Excuse Type Model was found for revenge $(B F=1.07)$. Anecdotal evidence for the Null Model was found for benevolence $(\mathrm{BF}=0.72)$ and complaints $(\mathrm{BF}=0.49)$. Next, we compared the Excuse Type Model with the Main Effect Model (i.e., Excuse Type + Apology Type) 
and with the Interaction Model (i.e., Excuse Type + Apology Type + Excuse Type $x$ Apology Type). This revealed substantial to strong evidence in favor of the Excuse Type Model for all dependent variables $(3.09 \leq \mathrm{BF} \leq 70.00)$. In summary, the Bayesian analysis confirmed that specific excuses were perceived as more acceptable and that these excuses reduced perceived responsibility, increased forgiveness, and reduced avoidance. Moreover, it also provided evidence against the hypothesis that there was a main effect of Apology Type or an interaction between Excuse Type and Apology Type.

TABLE 4.

Results of the Bayes factor ANOVA

\begin{tabular}{|l|c|c|c|}
\cline { 2 - 4 } \multicolumn{1}{c|}{} & $\begin{array}{c}\text { Excuse Type } \\
\text { Model }\end{array}$ & $\begin{array}{c}\text { Main Effect } \\
\text { Model }\end{array}$ & $\begin{array}{c}\text { Interaction } \\
\text { Model }\end{array}$ \\
\hline Acceptability & 4342.69 & 1404.30 & 501.88 \\
\hline Responsibility & 4640.88 & 1462.03 & 771.61 \\
\hline Forgiveness & 466.31 & 145.46 & 97.77 \\
\hline Benevolence & 0.72 & 0.09 & 0.06 \\
\hline Avoidance & 22.50 & 3.17 & 0.57 \\
\hline Revenge & 1.07 & 0.19 & 0.06 \\
\hline Complaints & 0.49 & 0.05 & 0.01 \\
\hline
\end{tabular}

Note. Each cell shows the Bayes factor for the Excuse Type Model, the Main Effect Model (Excuse Type + Apology Type), and the Interaction Model (Excuse Type + Apology Type + Excuse Type $x$ Apology Type) relative to the null model with both Train Travel Frequency and Train Delay Frequency as nuisance variables.

\section{Path Analysis}

To understand the mechanism through which excuse specificity influenced forgiveness and avoidance, we furthermore performed a path analysis in which we tested the hypothesis that a specific excuse is more acceptable and that an acceptable excuse is more likely to reduce the perceived responsibility of the railway company. Two models were compared in the path analysis, namely a model in which the influence of acceptability on forgiveness and avoidance was completely explained by perceived responsibility (Model 1) and a model in which the influence of acceptability on forgiveness and avoidance was partially explained by perceived responsibility (Model 2).

Model fit was evaluated on the basis of the Comparative Fit Index (CFI) and the Standardized Root Mean Squared Residual (SRMR) because Monte Carlo simulation studies have shown that a cutoff criterion of $C F I \geq 0.96$ combined with a cutoff criterion of SRMR $\leq 0.09$ minimizes the risk of rejecting a true model or accepting a false model (Hu \& Bentler, 1999). In addition, we included the Expected Cross Validation Index (ECVI) because this fit index takes into account model parsimony when assessing model fit. The ECVI is a comparative fit index that can be used to compare different models (Schermelleh-Engel, Moosbrugger, \& Müller, 2003). The model with the lowest ECVI is preferred over the alternative models. Note that we chose not to report the Root Mean Square Error of Approximation (RMSEA) because it has been shown that RMSEA based 
decisions inflate the risk of rejecting true models when the sample size and number of $d f s$ is small, as is the case in the current study (Kenny, Kaniskan, \& McCoach, 2014).

The evaluation of Model 1 revealed that it did not fit the data well, $\chi^{2}(5)=28.83, p<$ $0.001, \mathrm{CFI}=0.87, \mathrm{SRMR}=0.12$. Model 2 , on the other hand, did provide a good fit of the data, $\chi^{2}(3)=9.34, p=0.025, \mathrm{CFI}=0.97, \mathrm{SRMR}=0.07$, and proved to be a significant improvement over Model 1, $\chi^{2}$ diff $(2)=19.49, \mathrm{p}<0.001, \Delta_{\mathrm{ECVI}}=0.12$ (Figure 1). This analysis thus indicates that specific excuses are more acceptable and that a reduction in perceived responsibility can partially explain why acceptable excuses are more effective in terms of forgiveness and avoidance.

\section{FIGURE 1.}

visual representation of model 2. One-sided arrows reflect standardized regression coefficients. Double-sided arrows represent correlation coefficients. Legend: Spec $=$ specificity, Acc $=$ acceptability, Resp $=$ perceived responsibility, Forg $=$ forgiveness, Avoid $=$ avoidance. Note that all reported coefficients were significant $(p \leq 0.020)$

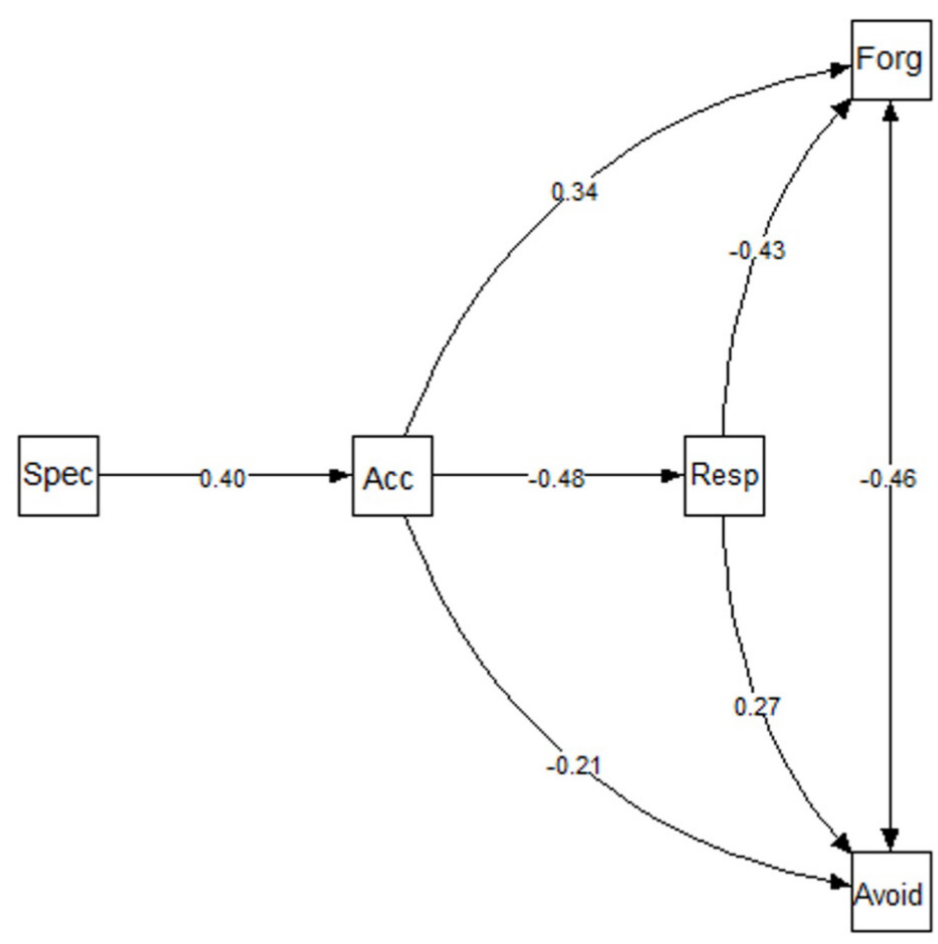

\section{Discussion}

From an environmental perspective, an important societal challenge is to encourage individuals to make use of sustainable modes of transportation such as public rail transport. However, a weakness of rail transport is its punctuality. When passengers purchase a ticket, they expect their train to arrive on time. As a result, train delays have important reputational and financial costs (Brown \& Beltramini, 1989; Folkes et al., 1987; Wang \& Huff, 2007). One way to reduce these costs is to provide an excuse that points out the external forces contributing to the delay (Kim et al., 2009; Shaw et al., 2003; Snyder \& Higgins, 1988). An efficient way to communicate such excuses to the passengers is to incorporate them in the message that announces the delay. However, excuses should be applied carefully because research suggests that unconvincing accounts can undermine their purpose (Ferrin et al., 2007; Kim et al., 2009). The 
current study therefore investigated how train delay excuses are best implemented by examining whether minor changes to these excuses can influence how passengers experience the delay. First, we compared the effectiveness of specific and non-specific excuses for train delay. Second, we explored the influence of adding an apology to these excuses. Finally, we tested if the influence of the apology differed depending on whether it referred to the cause or the consequence of the delay.

With regard to excuse specificity, the results revealed that participants who received a specific excuse were more likely to forgive the railway company and less likely to look for an alternative mode of transportation in the future. Importantly, this suggests that excuse specificity may not only influence passengers' attitude towards the railway company but also the number of passengers that drop out. As such, providing specific excuses can be seen as a low-cost measure to mitigate the passenger loss caused by train delays. To understand the mechanism through which these effects arose, we focused on the role of acceptability (Bies et al., 1988; Frey \& Cobb, 2010; MansourCole \& Scott, 1998; Mellor, 1992; Shapiro, 1991; Shaw et al., 2003) and perceived responsibility (Frey \& Cobb, 2010; Gilliland et al., 2001; Shaw et al., 2003). This revealed that specific excuses were evaluated as more acceptable (Frey \& Cobb, 2010) and that acceptable excuses produced favorable outcomes because they reduced doubt regarding the responsibility of the railway company (Frey \& Cobb, 2010; Gilliland et al., 2001; Shaw et al., 2003). However, perceived responsibility could only partially explain the role of acceptability. This suggests that additional mechanisms contributed to the relation between excuse acceptability and excuse effectiveness. One possibility is that acceptable excuses also reduced the emotional impact of train delays. In support of this idea, Weiner and colleagues (1987) showed that excuses referring to an external cause reduce feelings of anger more effectively than excuses referring to an internal cause.

With regard to the addition of an apology, the results showed that concluding the delay announcement with an apology did not influence the effectiveness of the preceding excuse. This speaks against a large body of research showing that apologies are an effective way of repairing trust (Bisel \& Messersmith, 2012; Ferrin et al., 2007; Koehn, 2013; Ohbuchi et al., 1989; Patel \& Reinsch, 2003; Risen \& Gilovich, 2007; Roschk \& Kaiser, 2013). However, such research did not study apologies in the context of excuses. Because excuses achieve trust repair through external attribution and apologies through internal attribution, it has been suggested that they could potentially counteract one another (Kim et al., 2009; Tomlinson et al., 2004). The current study did not find evidence for this proposition. Specifically, neither an apology with high internal attribution (i.e., referring to the cause) nor an apology with low internal attribution (i.e., referring to the consequence) influenced the effectiveness of the excuse. However, the absence of a difference between these two types of apology should be interpreted with caution because the manipulation check suggested that participants did not perceive them differently. Restricting interpretation to the presence or absence of an apology, our results indicate that the addition of an apology had neither positive nor negative consequences. At least two explanations can be put forward for this finding. First, it could be argued that the study had insufficient statistical power to detect an influence of apologies on excuse effectiveness. However, this is unlikely considering that 
a Bayesian analysis indicated substantial to strong evidence against an effect of apology type. Second, it is possible that the apology was not perceived as sincere in this context. Indeed, the scripted use of apologies in public transport communication possibly causes them to be perceived as less spontaneous and sincere. Given that these are important factors in determining the effectiveness of apologies (Koehn, 2013; Roschk \& Kaiser, 2013; Tomlinson et al., 2004), it is possible that scripted apologies do not possess the necessary elements to produce an effect.

In short, the current study shows that the degree of message specificity but not the addition of an apology has an influence on the effectiveness of excuses following train delay. These findings show how minor adjustments to the communication strategy of public transport organizations can assist in preserving and restoring commuter trust in the face of delays. However, it is of note that the present work was restricted to situations where the railway company was not responsible for the delay. Although this situation is common (Infrabel, 2016), it is not always possible to attribute a delay to external factors. In such cases, it seems implausible that providing detailed information about the cause of a delay has favorable consequences. Importantly, this does not imply that public transport agencies should also attribute delays that could have been avoided to external factors. Apart from ethical considerations, research suggests that a denial of responsibility is associated with worse outcomes than an apology if later evidence refutes the denial (Kim, Ferrin, Cooper, \& Dirks, 2004). It is therefore unlikely that such a strategy will be successful in the long run. Given these considerations, an interesting question is how delay announcements can be optimized in situations without an external cause. Because responsibility cannot easily be deflected in these situations, one possibility is that apologies gain importance in such events.

A further question that merits attention is the extent to which drop-out following train delay depends on the availability of transport alternatives. An interesting framework in this respect is the ASE model (De Vries, Dijkstra, \& Kuhlman, 1988) which posits that the transition from intention to action depends on skills (e.g. driver license) and barriers (e.g. car ownership). From this perspective, a delayed passenger without a car is less likely to follow up on his/her intention of looking for alternative modes of transportation. Nevertheless, meta-analytic work suggests that intentions are a consistent predictor of subsequent behavior under a wide range of conditions (Webb \& Sheeran, 2006). This suggests that obstacles reduce but do not eliminate the probability that individuals follow up on their intention. For example, individuals who do not own a car could avoid public transport by considering alternatives such as carpooling. Future research will be necessary to establish the influence of skills and barriers on avoidance of public transport following delay.

To conclude, the present study shows that railway passengers are less inclined to look for another mode of transportation following train delay when they are provided with a detailed rather than an abstract excuse. This finding offers railway companies an efficient and low-cost measure to reduce passenger loss associated with delay. 


\section{References}

Bies, R. J., Shapiro, D. L., \& Cummings, L. L. (1988). Causal Accounts and Managing Organizational Conflicts: Is it Enough to Say It's Not My Fault? Communication Research, 15, 381-399. http://doi.org/10.1177/009365088015004003

Bisel, R. S., \& Messersmith, A. S. (2012). Organizational and Supervisory Apology Effectiveness: Apology Giving in Work Settings. Business Communication Quarterly, 75(4), 425-448. http://doi.org/10.1177/1080569912461171

Brown, S. P., \& Beltramini, R. F. (1989). Consumer Complaining and Word of Mouth Activities: Field Evidence. Advances in Consumer Research, 16, 9-16.

De Vries, H., Dijkstra, M., \& Kuhlman, P. (1988). Self-efficacy: The Third Factor Besides Attitude and Subjective Norm as a Predictor of Behavioural Intentions. Health Education Research, 3, 273-282.

Ferrin, D. L., Kim, P. H., Cooper, C. D., \& Dirks, K. T. (2007). Silence Speaks Volumes: The Effectiveness of Retinence in Comparison to Apology and Denial for Responding to Integrity- and Competence-Based Trust Violations. Journal of Applied Psychology, 92, 893-908. http://doi.org/10.1037/0021-9010.92.4.893

Folger, R., \& Cropanzano, R. (2001). Fairness Theory: Justice as Accountability. In J. Greenberg \& R. Cropanzano (Eds.), Advances in Organizational Justice (pp. 1-55). Stanford, CA: Stanford University Press.

Folkes, V. S., Koletsky, S., \& Graham, J. L. (1987). A Field Study of Causal Inferences and Consumer Reaction: The View from the Airport. Journal of Consumer Research, 13, 534-539. http://doi.org/10.1086/209086

Frey, F. M., \& Cobb, A. T. (2010). What Matters in Social Accounts? The Roles of Account Specificity, Source Expertise, and Outcome Loss on Acceptance. Journal of Applied Social Psychology, 40(5), 1203-1234. http://doi.org/10.1111/j.1559-1816.2010.00616.x

Gilliland, S. W., Groth, M., Baker, R. C., Dew, A. F., Polly, L. M., \& Langdon, J. C. (2001). Improving Applicants' Reactions to Rejection Letters: An Application of Fairness Theory. Personnel Psychology, 54(3), 669-703. http://doi. org/10.1111/j.1744-6570.2001.tb00227.x

Greenberg, J. (1993). Stealing in the Name of Justice: Information and Interpersonal Moderators of Theft Reactions to Underpayment Inequity. Organizational Behavior and Human Decision Processes, 54, 81-103. http://doi.org/10.1006/obhd.1993.1004

Greenberg, J. (1994). Using Socially Fair Treatment to Promote Acceptance of a Work Site Smoking Ban. Journal of Applied Psychology, 79(2), 288-297. http://doi. org/10.1037/0021-9010.79.2.288

Holm, S. (1979). A Simple Sequentially Rejective Multiple Test Procedure. Scandinavian Journal of Statistics, 6(2), 65-70. 
Hu, L., \& Bentler, P. M. (1999). Cutoff Criteria for Fit Indexes in Covariance Structure Analysis: Conventional Criteria Versus New Alternatives. Structural Equation Modeling: A Multidisciplinary Journal, 6(1), 1-55. http://doi. org/10.1080/10705519909540118

Infrabel. (2016). Stiptheidscijfers 2015 [Punctuality Statistics 2015]. Retrieved from http://www.infrabel.be/nl/over-infrabel/stiptheid/rapporten/2015/1-0

Jeffreys, H. (1961). Theory of Probability (3rd ed.). Oxford, UK: Oxford University Press.

Kenny, D. A., Kaniskan, B., \& McCoach, D. B. (2014). The Performance of RMSEA in Models With Small Degrees of Freedom. Sociological Methods \& Research. http:// doi.org/10.1177/0049124114543236

Kim, P. H., Dirks, K. T., \& Cooper, C. D. (2009). The Repair of Trust: A Dynamic Bilateral Perspective and Multilevel Conceptualization. Academy of Management Review, 34(3), 401-422. http://doi.org/10.5465/AMR.2009.40631887

Kim, P. H., Ferrin, D. L., Cooper, C. D., \& Dirks, K. T. (2004). Removing the Shadow of Suspicion: the Effects of Apology Versus Denial for Repairing Competence- Versus Integrity-Based Trust Violations. The Journal of Applied Psychology, 89(1), 104-118. http://doi.org/10.1037/0021-9010.89.1.104

Koehn, D. (2013). Why Saying “I'm Sorry” Isn't Good Enough: The Ethics of Corporate Apologies. Business Ethics Quaterly, 23(2), 239-268. http://doi.org/10.5840/ beq201323216

Love, J., Selker, R., Marsman, M., Jamil, T., Dropmann, D., Verhagen, A. J., ... Wagenmakers, E.-J. (2015). JASP.

Mansour-Cole, D. M., \& Scott, S. G. (1998). Hearing it Through the Grapevine: The Influence of Source, Leader-Relations, and Legitimacy on Survivors' Fairness Perceptions. Personnel Psychology, 51, 25-54. http://doi. org/10.1111/j.1744-6570.1998.tb00715.x

McCullough, M. E., Root, L. M., \& Cohen, A. D. (2006). Writing About the Benefits of an Interpersonal Transgression Facilitates Forgiveness. Journal of Consulting and Clinical Psychology, 74, 887-897. http://doi.org/10.1037/0022-006X.74.5.887

Mellor, S. (1992). The Influence of Layoff Severity on Postlayoff Union Commitment Among Survivors: The Moderating Effect of the Perceived Legitimacyof a Layoff Account. Personnel Psychology, 45, 579-600. http://doi. org/10.1111/j.1744-6570.1992.tb00861.x

Ohbuchi, K., Kameda, M., \& Agarie, N. (1989). Apology as Aggression Control : Its Role in Mediating Appraisal of and Response to Harm. Journal of Personality and Social Psychology, 56(2), 219-227. http://doi.org/10.1037/0022-3514.56.2.219

Patel, A., \& Reinsch, L. (2003). Companies Can Apologize: Corporate Apologies and Legal Liability. Business Communication Quarterly, 66(1), 9-25. http://doi. org/10.1177/108056990306600103 
R Development Core Team. (2013). R: A Language and Environment for Statistical Computing. $R$ Foundation for Statistical Computing, Vienna, Austria.

Riordan, C. A., Marlin, N. A., \& Kellogg, R. T. (1983). The Effectiveness of Accounts Following Transgression. Social Psychology Quarterly, 46(3), 213. http://doi. org/10.2307/3033792

Risen, J. L., \& Gilovich, T. (2007). Target and Observer Differences in the Acceptance of Questionable Apologies. Journal of Personality and Social Psychology, 92(3), 418433. http://doi.org/10.1037/0022-3514.92.3.418

Roschk, H., \& Kaiser, S. (2013). The Nature of an Apology: An Experimental Study on How to Apologize After a Service Failure. Marketing Letters, 24(3), 293-309. http:// doi.org/10.1007/s11002-012-9218-x

Rosseel, Y. (2012). lavaan: An R Package for Structural Equation Modeling. Journal of Statistical Software, 48, 1-36.

Rouder, J. N., Morey, R. D., Speckman, P. L., \& Province, J. M. (2012). Default Bayes Factors for ANOVA Designs. Journal of Mathematical Psychology, 56(5), 356-374. http://doi. org/10.1016/j.jmp.2012.08.001

Schermelleh-Engel, K., Moosbrugger, H., \& Müller, H. (2003). Evaluating the Fit of Structural Equation Models : Tests of Significance and Descriptive Goodness-of-Fit Measures. Methods of Psychological Research Online, 8(2), 23-74.

Shapiro, D. L. (1991). The Effects of Explanations on Negative Reactions to Deceit. Administrative Science Quarterly, 36, 614-630. http://doi.org/10.2307/2393276

Shapiro, D. L., Buttner, E. H., \& Barry, B. (1994). Explanations: What Factors Enhance Their Perceived Adequacy? Organizational Behavior and Human Decision Processes, 58, 346-368. http://doi.org/10.1006/obhd.1994.1041

Shaw, J. C., Wild, E., \& Colquitt, J. A. (2003). To Justify or Excuse?: A Meta-Analytic Review of the Effects of Explanations. Journal of Applied Psychology, 88(3), 444-458. http:// doi.org/10.1037/0021-9010.88.3.444

Snyder, C. R., \& Higgins, R. L. (1988). Excuses: Their Effective Role in the Negotiation of Reality. Psychological Bulletin, 104(1), 23-35. http://doi.org/10.1037/00332909.104.1.23

Subkoviak, M. J., Enright, R. D., Wu, C.-R., Gassin, E. A., Freedman, S., Olson, L. M., \& Sarinopoulos, I. (1995). Measuring Interpersonal Forgiveness in Late Adolescence and Middle Adulthood. Journal of Adolescence, 18, 641-655.

Test-Aankoop. (2015). Treinreizigers Ontevreden: Dienstverlening NMBS Moet Beter! [Railway Passengers Dissatisfied: NMBS Service Must Improve!]. Retrieved from http://www.test-aankoop.be/action/pers informatie/persberichten/2015/nmbs

Tomlinson, E. C., Dineen, B. R., \& Lewicki, R. J. (2004). The Road to Reconciliation: Antecedents of Victim Willingness to Reconcile Following a Broken Promise. Journal of Management, 30(2), 165-187. http://doi.org/10.1016/j.jm.2003.01.003 
Wang, S., \& Huff, L. C. (2007). Explaining Buyers' Responses to Sellers' Violation of Trust. European Journal of Marketing, 41(9), 1033-1052. http://doi. org/10.1108/03090560710773336

Webb, T. L., \& Sheeran, P. (2006). Does Changing Behavioral Intentions Engender Behavior Change? A Meta-Analysis of the Experimental Evidence. Psychological Bulletin, 132(2), 249-268. http://doi.org/10.1037/0033-2909.132.2.249

Weiner, B., Amirkhan, J., Folkes, V. S., \& Verette, J. A. (1987). An Attributional Analysis of Excuse Giving: Studies of a Naive Theory of Emotion. Journal of Personality and Social Psychology, 52(2), 316-324. http://doi.org/10.1037/0022-3514.52.2.316

\section{About the Authors}

Emiel Cracco is a Ph.D. student at the Department of Experimental Psychology of Ghent University. His doctoral research focuses on action observation in social interactions that include multiple agents. However, he is also interested in the psychological aspects of public transport use and in emotion regulation in children and adolescents.

Nicolas DiRix is a PhD student at the Department of Experimental Psychology of Ghent University. He is currently affiliated with the "Language, Education, and Memory in Multilingualism and Academia" project (LEMMA), in which differences between first and second language processing and production are studied. In his part of the project, he studies eye movement data of bilingual students reading and studying in their first and second language.

Chris Reinders Folmer is a post-doctoral researcher at the research program Behavioural Approaches to Contract and Tort, affiliated with the Rotterdam Institute of Private Law and the Rotterdam Institute of Law and Economics. His background is in social and economical psychology (PhD 2008, Vrije Universiteit Amsterdam). His research integrates psychological, legal and economic perspectives to empirically test the assumptions that underlie legal practice and policy making, identify possible discrepancies, and develop alternatives informed by these perspectives. His research interests include legal psychology, trust, decision making, social dilemmas, ethics, and reputation.

\section{Footnotes}

\section{Footnote 1}

Note that the excuses and apologies were validated in a pilot study $(\mathrm{N}=18)$ including 16 specific excuses and 7 non-specific excuses that were paired with an apology for the cause or an apology for the consequence. Based on the results from this study, we chose the excuses that differed maximally with respect to specificity, $t(17)=9.56, \mathrm{p}$ $<0.001$, and minimally with respect to realism, $t(17)=-0.93, p=0.365$. The apologies were compared on the degree to which they referred to the cause or consequence 
of the delay. This showed that the cause apology referred more to the cause than the consequence apology, $t(17)=13.67, p<0.001$, and that the consequence apology referred more to the consequence than the cause apology, $t(17)=-3,75, p=0.002$.

\section{Supplementary Material: Scenario}

\section{Scenario in Dutch}

Gelieve je de volgende situatie aandachtig te lezen en zo levendig mogelijk in te beelden: Het is vrijdagnamiddag. Al je lessen zijn achter de rug en je bent gepakt en gezakt onderweg naar station Gent-Sint-Pieters om de trein te nemen naar Antwerpen. Je komt goed op tijd aan in het station en begeeft je vervolgens naar perron 1, waar je samen met enkele tientallen mede-passagiers wacht op het aankomen van de trein. Plots weerklinkt de volgende boodschap door de luidsprekers:

"Aandacht, spoor 1! Vanwege een koperdiefstal ter hoogte van Lokeren [specifiek] I Vanwege problemen op het spoor [vaag] heeft de trein van Gent-Sint-Pieters naar Antwerpen centraal van $16 u 05$ een vertraging van ongeveer 20 minuten. Onze verontschuldigingen voor het ongemak [gevolg] / voor dit voorval [oorzaak] / [geen]."

\section{Scenario in English}

Please carefully read the following situation and try to imagine it as vividly as possible: It is a Friday afternoon. Your classes are over and you are, packed and ready, on your way to the station of Ghent to take the train to Antwerp. You arrive well in time at the station and you go to platform 1 where you await the arrival of the train with a few dozen fellow travelers. Suddenly, the following message is played through the speakers:

"Attention, platform 1! Due to a copper theft in the vicinity of Lokeren [specific] / due to problems on the railway track [vague], the 16:05 train from Ghent to Antwerp is delayed by approximately 20 minutes. Our apologies for the inconvenience [consequence] / Our apologies for the incident [cause] / [none]."

\section{Supplementary Material: Questionnaires}

All items were measured on a 7-point Likert scale ( 1 = "Strongly Disagree", 7 = "Strongly Agree"). 


\section{Acceptability}

Gelieve aan te geven in welke mate je het eens bent met de volgende stellingen.

1. De uitleg bevat onvoldoende informatie

2. De uitleg is adequaat

3. De uitleg is aanvaardbaar

4. Ik zou tevreden zijn met de uitleg

5. De uitleg is niet geloofwaardig

6. De uitleg is redelijk

Please indicate to what extent you agree with the following statements.

1. The explanation does not contain enough information

2. The explanation is adequate

3. The explanation is acceptable

4. I would be satisfied with the explanation

5. The explanation is not credible

6. The explanation is reasonable

\section{Perceived Responsibility}

Gelieve aan te geven in welke mate je het eens bent met de volgende stellingen.

1. Volgens mij kon de NMBS deze vertraging hebben vermeden

2. Volgens mij was de vertraging het gevolg van oncontroleerbare omstandigheden

3. Volgens mij lag de NMBS aan de oorzaak van de vertraging

Please indicate to what extent you agree with the following statements.

1. I think the railway company could have avoided this delay

2. I think the delay was caused by uncontrollable circumstances

3. I think the railway company was at the cause of the delay

\section{Forgiveness}

Gelieve aan te geven in welke mate de volgende stellingen voor jou van toepassing zijn.

1. Na het horen van deze uitleg zou ik de NMBS kunnen vergeven voor de vertraging

2. Ondanks het horen van deze uitleg zou ik boos zijn op de NMBS

3. Ondanks het horen van deze uitleg zou mijn vertrouwen in de NMBS geschonden zijn

4. Na het horen van deze uitleg zou ik begrip kunnen opbrengen voor de vertraging

5. Ondanks het horen van deze uitleg zou ik de NMBS deze situatie kwalijk nemen 
Please indicate to what extent the following statements apply to you.

1. After hearing this explanation, I would be able to forgive the railway company for the delay

2. Despite hearing this explanation, I would be angry at the railway company

3. Despite hearing this explanation, my trust in the railway company would have been violated

4. After hearing this explanation, I would be understanding of the delay

5. Despite hearing this explanation, I would blame the railway company for this delay

\section{Revenge}

Gelieve aan te geven in welke mate de volgende stellingen voor jou van toepassing zijn.

1. Na het horen van deze uitleg zou ik de NMBS ongeluk toewensen.

2. Ondanks het horen van deze uitleg zou ik het de NMBS betaald willen zetten

3. Ondanks het horen van deze uitleg zou ik hopen dat de NMBS krijgt wat ze verdient

Please indicate to what extent the following statements apply to you.

1. After hearing this explanation, I would wish misfortune on to the railway company

2. Despite hearing this explanation, I would want to get even with the railway company

3. Despite hearing this explanation, I would hope that the railway company gets what it deserves

\section{Avoidance}

Ondanks de omgeroepen uitleg zou de vertraging me aanzetten...

1. ...tot het overwegen van andere vervoersalternatieven

2. ...om in het vervolg de trein te vermijden

3. ...om niet meer met de trein te reizen

4. ...om de NMBS te vermijden in de toekomst

5. ...om zoveel mogelijk afstand te houden van de NMBS

6. Ondanks het horen van deze uitleg zou ik geen vertrouwen meer hebben in de NMBS

Despite this explanation the delay would make me...

1. ... consider other transportation alternatives

2. ... avoid the train in the future

3. ... travel no longer by train 
4. ... avoid the railway company in the future

5. ... take as much distance as possible from the railway company

6. Despite hearing this explanation, I would no longer trust the railway company

\section{Benevolence}

Gelieve aan te geven in welke mate de volgende stellingen voor jou van toepassing zijn.

1. Ook al ben ik benadeeld, zou ik na het horen van deze uitleg welwillend staan tegenover de NMBS

2. Na het horen van deze uitleg zou ik geen wrok koesteren tegenover de NMBS

Please indicate to what extent the following statements apply to you.

1. Even though I'm disadvantaged, I would have goodwill for the railway company after hearing this explanation

2. After hearing this explanation, I would not hold a grudge against the railway company

\section{Complaints}

Ondanks de omgeroepen uitleg zou de vertraging me aanzetten...

1. ...tot klagen mijn vrienden/familie

2. ...tot het schrijven van een klachtenbrief naar de ombudsdienst van de NMBS

3. ...tot klagen bij de conducteur

4. ...tot klagen bij mijn mede-passagiers

Despite this explanation the delay would encourage me...

1. ... to complain to my friends / family

2. ... to write a letter of complaint to the ombudsman of the railway company

3. ... to complain to the conductor

4. ... to complain to my fellow passengers

\section{Manipulation check}

Gelieve aan te geven in welke mate de volgende stellingen voor jou van toepassing zijn.

1. Volgens mij verontschuldigde de de NMBS zich voor hetgene dat de vertraging heeft veroorzaakt

2. Volgens mij verontschuldigde de NMBS zich voor de last die ik ondervond van de vertraging

3. Ik vind de oorzaak van de vertraging realistisch

4. Ik vind de oorzaak van de vertraging onwaarschijnlijk 
5. Volgens mij treedt vertraging door deze oorzaak soms op in het echt

6. Ik vind de uitleg die voor de vertraging gegeven werd specifiek

7. Ik vind de uitleg die voor de vertraging gegeven werd vaag

8. Ik vind de uitleg die voor de vertraging gegeven werd gedetailleerd

9. Ik vind de uitleg die voor de vertraging gegeven werd uitgebreid

Please indicate to what extent the following statements apply to you.

1. I think the railway company apologized for the event that caused the delay

2. I think the railway company apologized for the inconvenience I experienced due to the delay

3. I think the cause of the delay is realistic

4. I find the cause of the delay unlikely

5. I believe that delays by this cause also occur in real life

6. I think the explanation for the delay was specific

7. I think the explanation for the delay was vague

8. I think the explanation for the delay was detailed

9. I think the explanation for the delay was extensive 